\title{
Ability of milk pH to predict subclinical mastitis and intramammary infection in quarters from lactating dairy cattle
}

\author{
S. A. Kandeel, ${ }^{1,2}$ A. A. Megahed, ${ }^{1,2}$ M. H. Ebeid, ${ }^{2}$ and P. D. Constable ${ }^{1 *}$ \\ ${ }^{1}$ Department of Veterinary Clinical Medicine, College of Veterinary Medicine, University of Illinois at Urbana-Champaign 61802 \\ ${ }^{2}$ Department of Animal Medicine, Faculty of Veterinary Medicine, Benha University, Kalyobiya, 13637, Egypt
}

\section{ABSTRACT}

Milk $\mathrm{pH}$ is increased in lactating dairy cattle with subclinical mastitis (SCM) and intramammary infection (IMI). We hypothesized that milk $\mathrm{pH}$ testing provides an accurate, low-cost, and practical on-farm method for diagnosing SCM and IMI. The main objective was to evaluate the clinical utility of measuring milk $\mathrm{pH}$ using 3 tests of increasing $\mathrm{pH}$ resolution: Multistix 10 SG Reagent Strips for Urinalysis (Multistix strips, Bayer HealthCare Inc., Elkhart, IN), pH Hydrion paper (Microessential Laboratory, Brooklyn, NY), and Piccolo plus pH meter (Hanna Instruments, Woonsocket, RI), for diagnosing SCM and IMI in dairy cattle. Quarter foremilk samples were collected from 115 dairy cows at dry off and 92 fresh cows within 4 to $7 \mathrm{~d}$ postcalving. Quarter somatic cell count (SCC) was measured using a DeLaval cell counter (DeLaval, Tumba, Sweden), with SCM defined as SCC >200,000 cells/mL and IMI defined as SCC $>100,000$ cells $/ \mathrm{mL}$ and the presence of microorganisms at $\geq 10 \mathrm{cfu} / \mathrm{mL}$ of milk. Milk $\mathrm{pH}$ was measured at $37^{\circ} \mathrm{C}$ using the 3 test methods. The Hydrion $\mathrm{pH}$ paper performed poorly in diagnosing SCM and IMI. Receiver operating curve analysis provided optimal $\mathrm{pH}$ cutpoints for diagnosing SCM for the $\mathrm{pH}$ meter (dry off, $\geq 6.67$; freshening, $\geq 6.52$ ) and Multistix strips (dry off and freshening, $\geq 7.0$ ). Test performance of the $\mathrm{pH}$ meter and Multistix strips was poor to fair based on area under the receiver operating curve, sensitivity, specificity, positive likelihood ratio, and kappa coefficient. The $\mathrm{pH}$ meter and Multistix strips performed poorly in diagnosing IMI at dry off and freshening. We concluded that milk $\mathrm{pH}$ does not provide a clinically useful method for diagnosing SCM or IMI in dairy cattle.

Key words: intramammary infection, subclinical mastitis, bromothymol blue, milk pH, cow-side test

Received April 29, 2018.

Accepted August 27, 2018.

*Corresponding author: constabl@illinois.edu

\section{INTRODUCTION}

Clinical mastitis and subclinical mastitis (SCM) are inflammatory conditions of the mammary gland that are accompanied by physicochemical alterations in milk along with pathological changes in the mammary gland (Constable et al., 2016). Clinical mastitis is defined as the presence of a visually abnormal secretion from one or more glands; an abnormal gland or systemic changes, such as pyrexia and inappetence, may also be present depending on the severity of the inflammation. In comparison, milk from quarters with SCM appears normal, and the presence of inflammation can only be detected using laboratory tests. Subclinical mastitis is most commonly due to an existing or recent infection of the mammary gland with a microorganism (Djabri et al., 2002), and an IMI is often defined as isolation of a microorganism following culture of a milk sample. It is important to realize, however, that in some cases the presence of microorganisms in milk is due to microbiological contamination during sampling rather than IMI, particularly in milk samples with low colony counts (<100 cfu/mL; Dohoo et al., 2011). A more appropriate definition of IMI, therefore, requires the concurrent presence of inflammation and isolation of a microorganism from the milk (Pyörälä, 2003). Accurate detection of IMI at dry off is essential if selective dry cow therapy is to be successfully implemented in the dairy industry.

Compositional changes of milk due to SCM or IMI reflect the degree of physical damage to the udder tissue. The blood-milk barrier is damaged in clinical mastitis and SCM and mammary epithelial tight junctions become leaky, leading to the escape of blood and extracellular fluid components into the lumen of the alveolus and a decrease in milk secretion rate (Nguyen and Neville, 1998). Blood and extracellular fluid components in inflamed quarters mix with secreted milk (Zhao and Lacasse, 2008) and increase milk pH, with the magnitude of the increase being positively associated with the severity of the inflammatory process (Ashworth et al., 1967; Wielgosz-Groth and Groth, 2003; Batavani et al., 2007; El Badawy et al., 2015; Qayyum et al., 
2016). Measurement of milk pH may therefore provide a useful test for identifying quarters with SCM and IMI, and consequently several studies were conducted in the 1920s and 1930s that evaluated milk pH as a diagnostic test (Baker and Breed, 1920; Stableforth, 1930; Udall and Johnson, 1931; Cherrington et al., 1933; Prouty, 1934). The test methodology at that time was laboratory based, and this requirement affected the widespread adoption of milk $\mathrm{pH}$ as a screening test for SCM and IMI.

Several inexpensive point-of-care methods are now available for the measurement of $\mathrm{pH}$ in biological fluids that can be readily adapted for on-farm or cow-side use. The relatively low cost (i.e., Piccolo plus $\mathrm{pH}$ meter $\approx \$ 220$; Hanna Instruments, Woonsocket, RI) and portability of $\mathrm{pH}$ meters make them potentially useful for on-farm use, and $\mathrm{pH}$ meters have been used to test colostral secretions at parturition to detect the presence of a persistent IMI based on increased secretion $\mathrm{pH}$ (Maunsell et al., 1998). Multistix strips (Bayer HealthCare Inc., Elkhart, IN) are widely available in North America and provide an inexpensive ( $\$ 0.30$ per test) point-of-care method that could be readily adapted for measuring milk $\mathrm{pH}$. The strips were originally designed for detecting urinary tract infection and kidney disorders in humans and were designed to measure urine $\mathrm{pH}$ in increments of 0.5 or $1.0 \mathrm{pH}$ units between $\mathrm{pH}$ of 5.0 and 8.5. The $\mathrm{pH}$ is estimated using a double indicator colorimetric system (methyl red, bromothymol blue) that produces a $\mathrm{pH}$-dependent change in color from orange $(\mathrm{pH}=5.0)$ passing through yellow and green to greenish-blue $(\mathrm{pH}=8.5)$. The Multistix strips were considered a promising candidate for the on-farm measurement of milk $\mathrm{pH}$ because bromothymol blue has been extensively used to diagnose SCM for $100 \mathrm{yr}$, initially as a test-tube laboratory test (Baker and Breed, 1920; Udall and Johnson, 1931; Prouty, 1934) and then as a cow-side test by applying a drop of milk to filter paper containing bromothymol blue (Marschke and Kitchen, 1985). A commercially available cellulose-based strip impregnated with bromothymol blue is available in India and the Middle East as a screening test for SCM (Mastrip, Ayurvet Ltd., Delhi, India; Langer et al., 2014; Sundareshan et al., 2014; Tawfik et al., 2014), but is not available in North America or Europe. Hydrion (Microessential Laboratory, Brooklyn, NY) pH paper is a commercially available colorimetric test paper for measuring urine and saliva $\mathrm{pH}$ between 5.5 and 8.0 in increments of $0.2 \mathrm{pH}$ units. The $\mathrm{pH}$ paper is inexpensive ( $\$ 0.04$ per test) and impregnated with proprietary indicator dyes that change color when the $\mathrm{pH}$ paper is in contact with fluid. We hypothesized that measuring milk pH using these point-of-care tests would provide an accurate, low-cost, and practical cow-side method for diagnosing SCM and IMI in lactating dairy cattle. The objective of our study was therefore to determine and compare the clinical utility of measuring milk $\mathrm{pH}$ using a $\mathrm{pH}$ meter, Multistix strips, and Hydrion $\mathrm{pH}$ paper to diagnose SCM or IMI in dairy cows at dry off and freshening.

\section{MATERIALS AND METHODS}

\section{Animals, Housing, Feeding, and Milking}

An observational study was conducted using a convenience sample of 115 dairy cows that were sampled during the last week of lactation and 92 dairy cows that were sampled 4 to $7 \mathrm{~d}$ postpartum. All methods were evaluated and approved by the University of Illinois Institutional Animal Care and Use Committee. The study reported here was part of a series of studies investigating the diagnosis of SCM and IMI in lactating dairy cattle. Additional results have been published elsewhere (Kandeel et al., 2017, 2018a,b, 2019).

The study was performed at the University of Illinois Dairy Research Farm over a period of 13 mo between July 1, 2015, and July 31, 2016. Cows were predominantly Holstein-Friesian, with a small number of Jersey, Ayrshire, Brown Swiss, and Milking Shorthorn animals. The median number of cows in the milking herd during the study was 136 and the average milk yield was $34.1 \mathrm{~kg} / \mathrm{cow}$ per day. The median monthly bulk tank milk SCC was 236,000 cells $/ \mathrm{mL}$ at $3.6 \%$ fat and $3.2 \%$ protein. The median standard plate count was 2,500 $\mathrm{cfu} / \mathrm{mL}$ (goal $<5,000 \mathrm{cfu} / \mathrm{mL}$ ), the median preliminary incubation count was $8,000 \mathrm{cfu} / \mathrm{mL}$ (goal $<10,000 \mathrm{cfu} /$ $\mathrm{mL}$ ), and the median monthly number of clinical mastitis episodes was 4.7 per 100 milking cows (goal $<2.0$; Constable et al., 2016).

Cows to be dried off were milked twice daily in a milking parlor at 0400 and $1600 \mathrm{~h}$, whereas cows after calving were milked 3 times daily at 0500, 1400, and $2130 \mathrm{~h}$. Cows with abnormal milk or udder were identified as clinical mastitis cases and not included in the study. A dry cow intramammary ceftiofur formulation (Spectramast DC, Zoetis Animal Health, Parsippany, NJ) followed by a dry cow teat sealant (Orbeseal, Zoetis Animal Health) were applied to all cows at dry off using procedures recommended by the manufacturers (https://www.zoetisus.com/products/dairy/).

Late-gestation cows were housed in a freestall barn and moved to a calving pen a few days before the anticipated date of calving. Fresh cows were kept in a tiestall barn for at least $3 \mathrm{~d}$ after calving or until they recovered from any postpartum health issues. The cows 
were then returned to the freestall barn and fed a lactating cow TMR based on formulations recommended by the NRC (2001). Data including breed, age, DIM, daily milk production, and parity were retrieved from the farm records using the dairy's automatic recording software (PCDart, DRMS, Ames, IA).

\section{Experimental Methods}

A farm visit was performed at least once a week to collect foremilk samples from each quarter separately in the same week of drying off between 1200 and 1600 $\mathrm{h}$ and at 4 to $7 \mathrm{~d}$ postpartum (to exclude the colostrum milk) between 1200 and $1400 \mathrm{~h}$. Cows at dry off were moved to a shaded area of the freestall and secured with the aid of a halter. Disposable gloves were applied before touching the udder. The teat end of each quarter was cleaned with alcohol 70\% (National Mastitis Council, 1999) and 20-mL milk samples were collected separately by hand stripping after discarding the first 3 squirts within $50 \mathrm{~s}$ of first touching any teat to ensure that samples reflected cisternal milk (Sarikaya and Bruckmaier, 2006). Samples were then stored in iced water in an insulated contained and transported to the dairy farm laboratory and then to a second laboratory at the College of Veterinary Medicine.

A physical examination was performed on each cow to identify the presence of systemic disorders. Udder and milk were examined by inspection and palpation to detect the presence of any abnormalities, including the cardinal signs of inflammation or abnormal milk.

\section{Milk Analysis for SCC}

The reference method for determining SCC in this study was the DeLaval cell counter (DCC; DeLaval International AB, Tumba, Sweden). The DCC method has been validated for bovine milk at 4 and $37^{\circ} \mathrm{C}$ against the Fossomatic (Foss, Hillerod, Denmark) and direct microscopic methods (Sarikaya and Bruckmaier, 2006; Malinowski et al., 2008; Kawai et al., 2013; Hanuš et al., 2014). The DCC is a portable automatic cell counter, with a reported measurement range of 10,000 to $4,000,000$ cells $/ \mathrm{mL}$. Samples were measured using the DCC at the University of Illinois Dairy Research Farm as recommended by the manufacturer (https:/ /dairyfocus.illinois.edu/content/dairy-cattle-research -unit). Approximately $1 \mu \mathrm{L}$ of foremilk was drawn into the single-use cassette and inserted into the DCC analyzer. The result was shown on the display after 45 $\mathrm{s}$ and indicated the number of cells per microliter of milk; this number was multiplied by 1,000 to provide the SCC in units of cells/mL of milk.

\section{Milk Analysis for $\mathrm{pH}$}

Milk pH was measured on quarter milk samples within $4 \mathrm{~h}$ of collection after transport back to a laboratory at the College of Veterinary Medicine. The 4-h period reflected workload constraints. Quarter milk samples were placed in a water bath at $37^{\circ} \mathrm{C}$ for at least $30 \mathrm{~min}$ to simulate the milk temperature for measurement of $\mathrm{pH}$ was measured as a cow-side test. Each milk sample was thoroughly mixed before evaluation. Foremilk $\mathrm{pH}$ was measured sequentially using 3 methods of increasing $\mathrm{pH}$ resolution: the Multistix strip, the Hydrion $\mathrm{pH}$ paper, and the $\mathrm{pH}$ meter.

Milk $\mathrm{pH}$ was measured using the Multistix $10 \mathrm{SG}$ urine test strip according to the instructions provided by the manufacturer (https://clinicallabs.osumc.edu/ Documents/Multistix\%20Package\%20Insert.pdf; Bayer HealthCare Inc.). The strips contain $0.2 \%$ wt/wt methyl red, $2.8 \%$ bromothymol blue, and $97.0 \%$ nonreactive ingredients. Methyl red changes color from red to yellow over the $\mathrm{pH}$ range of 4 to 6 , and bromothymol blue changes from yellow to green to blue over the $\mathrm{pH}$ range of 6 to 9 . One reagent strip was removed from the bottle and the reagent pads of the strip were completely immersed in a well-mixed milk sample. The test strip was removed from the tube, shaken to remove excess milk, and left to stand on a flat clean surface with the indicator pad facing up for $1 \mathrm{~min}$. The colors that appeared were compared against the chromatic scale on the vial provided by the manufacturer and recorded.

Milk $\mathrm{pH}$ was measured using Hydrion $\mathrm{pH}$ paper according to the instructions provided by the manufacturer (https://www.microessentiallab.com/ProductInfo/ F01-SHTRG-055080-SRD.aspx). Approximately $5 \mathrm{~cm}$ of $\mathrm{pH}$ paper was torn from the roll and a few drops of the milk sample applied to the paper. The paper was then turned on its side to drain excess sample and the color change matched immediately with the closest color on the supplied chart.

Milk $\mathrm{pH}$ was also measured using a Piccolo plus glass bulb single junction $\mathrm{pH}$ meter according to the instructions of the manufacturer (https://hannainst .com/downloads/dl/file/id/1894/manpiccolo.pdf). The electrode was connected to the meter and the meter calibrated using $\mathrm{pH}=7.0$ and 4.0 buffer solutions. After calibration, the electrode was dipped in the milk sample to be measured without exceeding the maximum immersion level. The $\mathrm{pH}$ of the sample was recorded after the reading had stabilized.

\section{Milk Culturing for Pathogen Isolation}

Milk culturing was performed based on NMC (1999) recommendations. Blood agar (TSA W/5\% sheep 
blood agar; Remel, Lenexa, KS) and MacConkey plates (Remel) were divided into 2 halves and labeled with the cow identification and quarter. Using a pipette and sterile pipette tips, a $0.1-\mathrm{mL}$ aliquot $(100 \mu \mathrm{L})$ of each quarter milk sample was placed on one-half of the blood agar and MacConkey plates separately, and then streaked using a sterile wire loop in a manner that permitted the growth of isolated bacterial colonies that was essential for accurate interpretation. The plates were then incubated in an inverted position at $37^{\circ} \mathrm{C}$ for $48 \mathrm{~h}$ and microbial growth and each colony type was recorded. The isolated pathogen was identified by colony morphology, hemolysis pattern, biochemical tests, including catalase and coagulase test, and Gram staining reaction and cell morphology according to NMC (1999) guidelines. The microbiological isolates are reported elsewhere (Kandeel et al., 2019).

\section{Statistical Analysis}

A statistical software program (SAS 9.4, SAS Institute Inc., Cary, NC) was used for all analyses and $P<$ 0.05 was considered significant. The least squares means milk $\mathrm{pH}$ and $95 \%$ confidence interval for the mean of healthy quarters (SCC $<100,000$ cells $/ \mathrm{mL}$; Cherrington et al., 1933; Pyörälä, 2003) was determined at dry off and freshening using mixed model analysis (PROC MIXED) with cow as a random effect and quarter nested within cow.

Spearman's correlation coefficients (PROC CORR) were calculated to characterize the curvilinear association between milk SCC and $\mathrm{pH}$ measured by the 3 methods for all quarters. Subclinical mastitis was defined on a quarter basis as SCC >200,000 cell/mL because this is the most frequently used method and cutoff value for diagnosing SCM, providing maximum sensitivity and specificity and minimal diagnostic error (Dohoo and Leslie, 1991; Schukken et al., 2003; Dohoo et al., 2011). Microbiological growth (MG) was defined as $\geq 100 \mathrm{cfu} / \mathrm{mL}$, equivalent to the isolation of a single colony from $10 \mu \mathrm{L}$ of milk (Dohoo et al., 2011) and equivalent to the isolation of at least 10 colonies from $100 \mu \mathrm{L}$ of milk in the study reported here. An IMI was defined as the presence of both SCC $>100,000$ cells/ $\mathrm{mL}$ and $\mathrm{MG}$ of $>10 \mathrm{cfu} / \mathrm{mL}$. The cutpoints for this category were lower than those used individually for SCM and MG because we were interested in optimizing the overall test sensitivity, with quarter SCC $<100,000$ cells/mL reflecting an internationally accepted definition of udder quarter health (Hamann, 2003; Pyörälä, 2003).

Logistic regression (PROC LOGISTIC) was used to characterize the relationship between SCM as determined by the reference method $(1=$ SCC $>200,000$ cells $/ \mathrm{mL} ; 0=\mathrm{SCC} \leq 200,000$ cells $/ \mathrm{mL}$ ), MG as determined by milk culture $(1:>100 \mathrm{cfu} / \mathrm{mL} ; 0:<100 \mathrm{cfu} /$ $\mathrm{mL}$ ), or IMI as determined by the presence of both SCM and MG and milk pH measured by the 3 methods at dry off and freshening. Receiver operating characteristic (ROC) curves were constructed for each logistic regression model. The area under the ROC curve (AUC) was calculated as a global index of test performance and compared using a nonparametric approach (DeLong et al., 1988); AUC values for ROC curves $>0.9$ typically indicate a highly accurate test, whereas AUC values of 0.7 to 0.9 indicates moderate accuracy, 0.5 to 0.7 low accuracy, and 0.5 represents a chance result (Swets, 1988). Sensitivity (Se) and specificity (Sp) were calculated at the optimal cutpoint of each ROC; the cutpoint was determined using the Youden index, which represents the maximum value for the expression $\mathrm{Se}+\mathrm{Sp}-1$. This method for determining the optimal cutpoint equally weights the value of Se and Sp. The positive likelihood ratio $(+\mathrm{LR})$ was calculated as $+\mathrm{LR}$ $=\mathrm{Se} /(1-\mathrm{Sp}) ;+\mathrm{LR}$ values $>10$ indicate that a positive test is good at ruling in a diagnosis (Grimes and Schulz, 2005), such as SCM or IMI. The kappa coefficient ( $\kappa$, PROC FREQ) was calculated using the optimal cutpoint of the ROC to characterize the level of agreement between milk $\mathrm{pH}$ and the 3 reference methods (SCM, $\mathrm{MG}$, and IMI). Values for $\kappa<0.2$ indicate poor agreement, whereas $0.2<\kappa<0.4$ indicates fair agreement, $0.4<\kappa<0.6$ indicates moderate agreement, $0.6<\kappa$ $<0.8$ reflects good agreement, and $\kappa>0.8$ indicates excellent agreement (Landis and Koch, 1977).

\section{RESULTS}

Somatic cell counts were obtained on 456 quarter milk samples at dry off from 115 cows, comprising 103 Holstein-Friesian, 8 Jersey, 2 Ayrshire, 1 Brown Swiss, and 1 Milking Shorthorn; 4 cows sampled at dry off had 1 blind quarter. Somatic cell counts were obtained on 364 quarter milk samples from 92 cows in early lactation, comprising 81 Holstein-Friesian, 8 Jersey, 1 Ayrshire, 1 Brown Swiss, and 1 Milking Shorthorn; 4 cows had 1 blind quarter.

\section{Diagnosis of SCM}

The prevalence of SCM, defined as SCC >200,000 cells $/ \mathrm{mL}$ on a quarter basis, was $68 \%$ at dry off and $33 \%$ at freshening. Scatterplots of the relationship between quarter $\mathrm{pH}$ and SCC at dry off and freshening are presented in Figure 1. The scatterplot indicates that $\mathrm{pH}$ increased as SCC increased above 100,000 to 200,000 cells $/ \mathrm{mL}$. The least squares means $\mathrm{pH}$ of quarter milk samples at $37^{\circ} \mathrm{C}$ from quarters with SCC 
$<100,000$ cells $/ \mathrm{mL}$ was higher $(P<0.0001)$ at dry off $(6.60 ; 95 \%$ CI for mean $=6.52$ to 6.68$)$ than at freshening $(6.40 ; 95 \%$ CI for mean $=6.36$ to 6.44$)$. The Spearman correlation coefficient for the association between the measured $\mathrm{pH}$ and SCC was highest for the Multistix strip at both dry off and freshening $\left(r_{\mathrm{s}}=0.61\right.$ and 0.50 , respectively; Table 1 ).

Values for the optimal cutpoint, AUC, Se, Sp, and +LR for diagnosing SCM at dry off and freshening determined using logistic regression analysis are presented in Table 2 and Figure 2. The AUC for the Multistix strip at dry off was similar $(P=0.12)$ to that of the $\mathrm{pH}$ meter; however, the AUC for the Multistix strip at
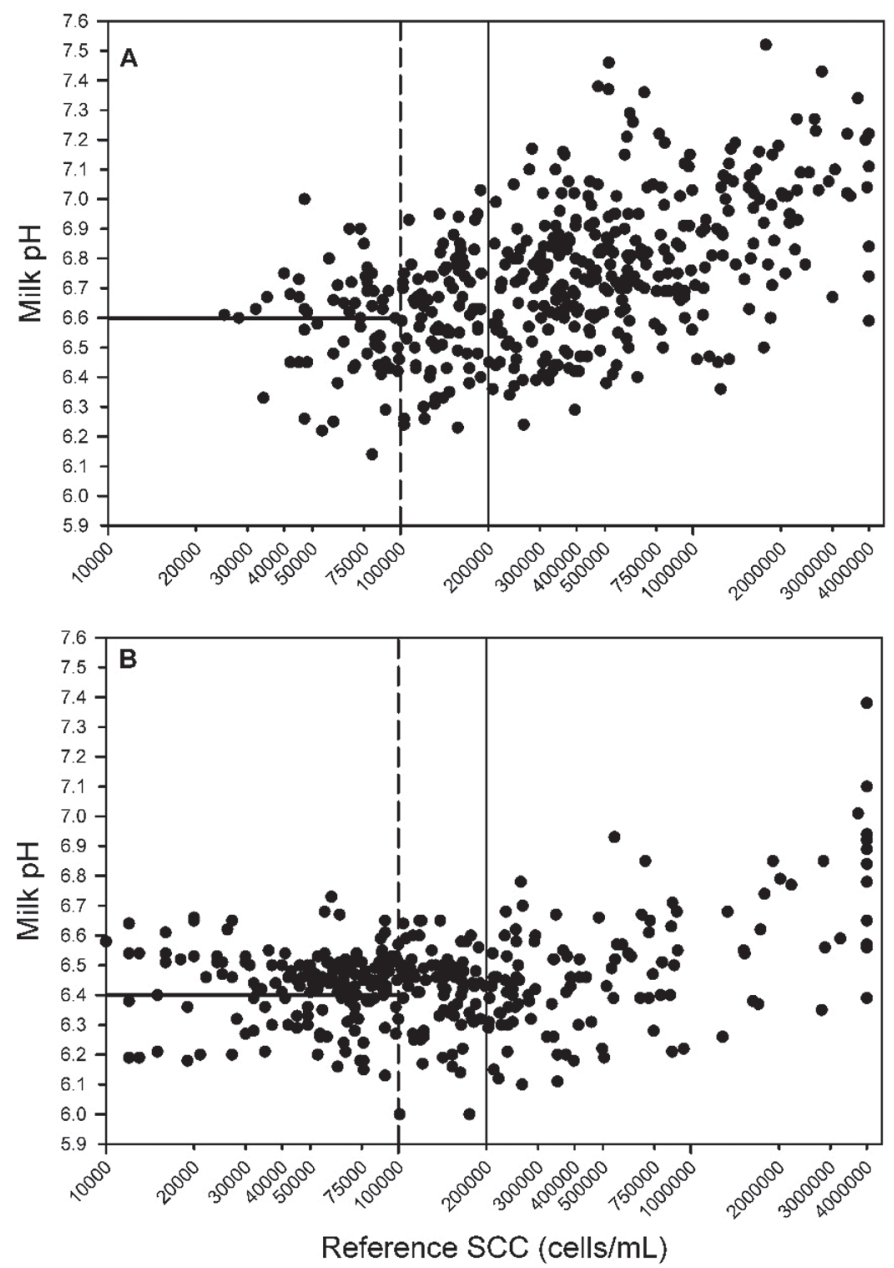

Figure 1. (A) Scatterplot of the relationship between quarter milk $\mathrm{pH}$ measured at $37^{\circ} \mathrm{C}$ and quarter SCC for cows at dry off. Data were obtained from 456 quarters from 115 cows. (B) Scatterplot of the relationship between quarter milk $\mathrm{pH}$ measured at $37^{\circ} \mathrm{C}$ and quarter $\mathrm{SCC}$ for cows at freshening. Data were obtained from 364 quarters from 92 cows. The vertical lines represent the limit for SCC of healthy quarters (SCC $<100,000$ cells/mL, dashed line) and the definition used in this study for diagnosing subclinical mastitis $(\mathrm{SCC}>200,000$ cells $/ \mathrm{mL}$, solid line). The horizontal solid line represents the least squares means $\mathrm{pH}$ for healthy quarters. freshening was greater than that of the $\mathrm{pH}$ meter $(P=$ 0.0050). The AUC for the Hydrion $\mathrm{pH}$ paper was lower than that of the $\mathrm{pH}$ meter at dry off $(P<0.0001)$ but not at freshening $(P=0.061)$. The $\kappa$ value using the optimal $\mathrm{pH}$ cutpoint for SCM was numerically highest for the Multistix strips at dry off and freshening (Table $2)$.

\section{Diagnosis of Microbiological Growth}

The prevalence of $\mathrm{MG}$, defined as $\geq 100 \mathrm{cfu} / \mathrm{mL}$ on a quarter basis, was $16 \%$ at dry off and $14 \%$ at freshening. Coagulase-negative staphylococci were the most common isolate, being present in $12.4 \%$ of quarters at dry off and $8.2 \%$ of quarters at freshening.

Values for the AUC, optimal cutpoint, Se, Sp, and +LR for diagnosing MG at dry off and freshening determined using logistic regression analysis are presented in Table 2 and Figure 3. The AUC for the Multistix strips at dry off was similar $(P=0.17)$ to that of the $\mathrm{pH}$ meter; however, the AUC for the Multistix strips at freshening was greater than that of the $\mathrm{pH}$ meter $(P=$ 0.0027). The AUC for the Hydrion $\mathrm{pH}$ paper was similar to that of the $\mathrm{pH}$ meter at dry off $(P=0.26)$ and freshening $(P=0.26)$. The $\kappa$ value using the optimal $\mathrm{pH}$ cutpoint for MG was poor for all comparisons ( $\kappa$ $<0.2$ ) except Multistix strips at freshening.

\section{Diagnosis of IMI}

The prevalence of IMI, defined as SCC $\geq 100,000$ cells $/ \mathrm{mL}$ and $\geq 10 \mathrm{cfu} / \mathrm{mL}$ on a quarter basis, was $25 \%$ at dry off and $17 \%$ at freshening. Values for the AUC, optimal cutpoint, Se, Sp, and +LR for diagnosing an IMI at dry off and freshening determined using logistic regression analysis are presented in Table 2 . The AUC for the Multistix strips at dry off was similar $(P=0.51)$ to that of the $\mathrm{pH}$ meter; however, the AUC for the Multistix strips at freshening was greater than that of the $\mathrm{pH}$ meter $(P=0.047)$. The AUC for the Hydrion $\mathrm{pH}$ paper was similar to that of the $\mathrm{pH}$ meter at dry off $(P=0.12)$ and freshening $(P=0.16)$. The $\kappa$ value using the optimal $\mathrm{pH}$ cut-point for IMI was poor at dry off $(\kappa<0.2)$ and fair at freshening for the Multistix strips and $\mathrm{pH}$ meter.

\section{DISCUSSION}

Our study compared the clinical utility of a glass electrode $\mathrm{pH}$ meter, Multistix strip, and Hydrion $\mathrm{pH}$ paper as cow-side tests for diagnosing SCM, MG, and IMI at dry off and freshening. The primary finding of our study was that milk $\mathrm{pH}$ does not provide sufficient test Se and Sp to identify quarters with SCM, MG, 
Table 1. Spearman correlation coefficients among variables of interest for 115 dairy cows at dry off ( 4 blind quarters) and 92 cows at freshening (4 blind quarters), with number of quarters used for comparison and the corresponding $P$-value in parentheses ${ }^{1}$

\begin{tabular}{|c|c|c|c|c|}
\hline Variable & $\begin{array}{c}\text { DeLaval } \\
\text { SCC }\end{array}$ & $\begin{array}{l}\text { Multistix } \\
\text { test strips }\end{array}$ & $\mathrm{pH}$ meter & $\begin{array}{l}\text { Hydrion } \\
\text { pH paper }\end{array}$ \\
\hline \multicolumn{5}{|l|}{ Dry off } \\
\hline DeLaval SCC & +1.00 & $\begin{array}{l}+0.61 \\
(456, P<0.0001)\end{array}$ & $\begin{array}{l}+0.52 \\
(456, P<0.0001)\end{array}$ & $\begin{array}{l}+0.36 \\
(456, P<0.0001)\end{array}$ \\
\hline Multistix test strips & & +1.00 & $\begin{array}{c}+0.79 \\
(456, P<0.0001)\end{array}$ & $\begin{array}{c}+0.49 \\
(456, P<0.0001)\end{array}$ \\
\hline $\mathrm{pH}$ meter & & & +1.00 & $\begin{array}{c}+0.42 \\
(456, P<0.0001)\end{array}$ \\
\hline Hydrion $\mathrm{pH}$ paper & & & & +1.00 \\
\hline \multicolumn{5}{|l|}{ Freshening } \\
\hline DeLaval SCC & +1.00 & $\begin{array}{l}+0.50 \\
(364, P<0.0001)\end{array}$ & $\begin{array}{l}+0.13 \\
(364, P<0.01)\end{array}$ & $\begin{array}{c}+0.19 \\
(364, P<0.0002)\end{array}$ \\
\hline Multistix test strips & & +1.00 & $\begin{array}{l}+0.48 \\
(364 P<0.0001)\end{array}$ & $\begin{array}{l}+0.36 \\
(364, P<0.0001)\end{array}$ \\
\hline $\mathrm{pH}$ meter & & & +1.00 & $\begin{array}{c}+0.19 \\
(364, P<0.0002)\end{array}$ \\
\hline Hydrion $\mathrm{pH}$ paper & & & & +1.00 \\
\hline
\end{tabular}

${ }^{1}$ DeLaval cell counter (DeLaval International AB, Tumba, Sweden); Multistix strips (Bayer HealthCare Inc., Elkhart, IN), pH Hydrion paper (Microessential Laboratory, Brooklyn, NY).

or IMI. This means that a clinically relevant number of mammary glands with SCM or an IMI will not be detected by measuring milk $\mathrm{pH}$, even when the optimal cutpoint is used. An additional finding was that the Multistix strip, when used at a cutpoint of $\geq 7.0$ to diagnose SCM, had a superior performance in fresh cows and similar performance to the $\mathrm{pH}$ meter at dry off, whereas the Hydrion $\mathrm{pH}$ paper did not appear to be accurate in a milk matrix.

The quarter was the unit of analysis used in our study and test performance was based on the assumption that both sensitivity and specificity were of equal importance. Therefore, the AUC, $+\mathrm{LR}$, and $\kappa$ coefficient provide useful clinical indices of the overall test performance for diagnosing SCM and IMI. The AUC for the $\mathrm{pH}$ meter and the Multistix strip indicated low to moderate accuracy at the optimal milk $\mathrm{pH}$ cutpoints for dry off and fresh cows. Using the same optimal cutpoints, the $\kappa$ coefficient indicated fair to moderate agreement for the $\mathrm{pH}$ meter and the Multistix strip. We elected not to report values for the predictive value of a positive test $(\mathbf{P V}+)$ or the predictive value of a negative test $(\mathbf{P V}-)$, as these 2 indices are influenced by the prevalence of disease in the tested population; this means that in a population with high disease prevalence, the PV+ estimate will always be higher than in a population with low disease prevalence. In contrast, estimates for Se, Sp, and +LR are characteristics of the test itself and are not influenced by disease prevalence.

The $\mathrm{pH}$ of bovine milk (nonmastitic and noncolostrum) is commonly stated to range between 6.4 and
6.8 (Schalm and Noorlander, 1957; White and Davies 1958); however, comparisons of milk $\mathrm{pH}$ need to be temperature adjusted, because milk $\mathrm{pH}$ decreases linearly as temperature increases $\left(-0.0106 \mathrm{pH}\right.$ unit $/{ }^{\circ} \mathrm{C}$, Dixon, $1963 ;-0.0073 \mathrm{pH}$ unit $/{ }^{\circ} \mathrm{C}$, Chaplin and Lyster, 1988; $-0.0078 \mathrm{pH}$ unit/ ${ }^{\circ} \mathrm{C}$; $\mathrm{Ma}$ and Barbano, 2003; $-0.0096 \mathrm{pH}$ unit $/{ }^{\circ} \mathrm{C}$; On-Nom et al., 2010). Based on our least squares means values for healthy quarters (SCC $<100,000$ cells/mL) at dry off and freshening and the mean value for the experimentally determined linear relationship between $\Delta \mathrm{pH} / \Delta \mathrm{T}(-0.009$; Dixon, 1963; Chaplin and Lyster, 1988; Ma and Barbano, 2003; On-Nom et al., 2010), we proposed that the value for temperature-corrected milk $\mathrm{pH}\left(\mathbf{p H}_{\mathrm{T}}=37 \mathrm{C}\right)$ from healthy quarters measured at temperature $\mathrm{T}$ in ${ }^{\circ} \mathrm{C}$ should be calculated for samples obtained at dry off as: $\mathrm{pH}_{\mathrm{T}}=37 \mathrm{C}=6.60+0.009 \times(37-\mathrm{T})$. For samples obtained at 4 to 7 DIM it should be calculated as: $\mathrm{pH}_{\mathrm{T}=37 \mathrm{C}}=6.40+0.009 \times(37-\mathrm{T})$. Many studies that have measured milk $\mathrm{pH}$ either do not report the milk temperature when measuring $\mathrm{pH}$ or include quarters with SCM, and therefore increased $\mathrm{pH}$, as demonstrated in our study (Figure 1). For example, Tsioulpas et al. (2007a,b) measured mean milk pH values of 6.49 and 6.63 at $20^{\circ} \mathrm{C}$ on $\mathrm{d} 5$ of lactation and throughout lactation, respectively. These measurements correspond to $\mathrm{pH}_{\mathrm{T}}=37 \mathrm{C}$ values of 6.54 and 6.78 , respectively, suggesting a moderate prevalence of SCM in the sampled cows. As another example, Klimes et al. (1986) measured a mean milk pH of 6.41 at approximately $20^{\circ} \mathrm{C}$ for cows on $\mathrm{d} 5$ of lactation, which corresponds to a $\mathrm{pH}_{\mathrm{T}}=37 \mathrm{C}$ 
of 6.56 , also suggesting a moderate prevalence of SCM in the sampled cows. It would therefore be interesting to measure the $\mathrm{pH}$ of a large number of bulk tank milk samples at a known temperature to determine how well bulk tank milk $\mathrm{pH}$ is correlated with bulk tank SCC.
If temperature-corrected bulk tank milk $\mathrm{pH}$ is well correlated with bulk tank SCC, daily measurement of bulk tank milk $\mathrm{pH}$ could provide a practical and inexpensive method to monitor the prevalence and severity of SCM in dairy herds. Support for this hypothesis is provided

Table 2. Summary of the results of logistic regression analysis of the ability of milk $\mathrm{pH}$ measured by Multistix test strips, $\mathrm{pH}$ meter, and Hydrion $\mathrm{pH}$ paper to predict subclinical mastitis, microbiological growth, and IMI in quarter milk samples obtained from dairy cows at dry off $(\mathrm{n}=115,4$ cows with 1 blind quarter $)$ and freshening $(\mathrm{n}=92,4 \text { cows with } 1 \text { blind quarter })^{1}$

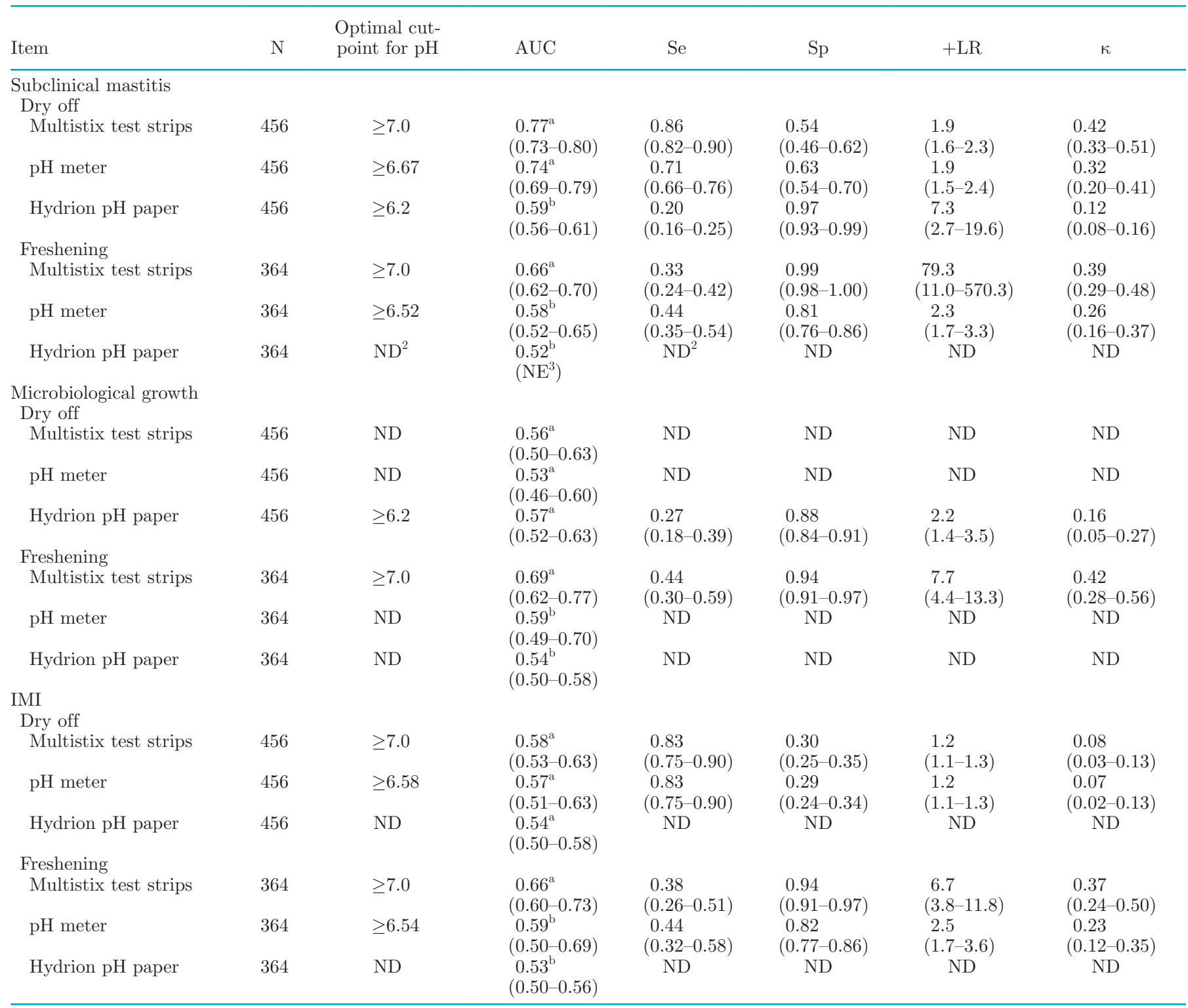

\footnotetext{
${ }^{a, b}$ Values for AUC with different superscripts within each of the 4 groups are significantly different.
}

${ }^{1}$ Subclinical mastitis was defined as a SCC $>200,000$ cells $/ \mathrm{mL}$ measured by the DeLaval cell counter. Microbiological growth was defined as isolation of $\geq 100 \mathrm{cfu} / \mathrm{mL}$ of milk. Intramammary infection was defined as the presence of both subclinical mastitis (SCC $\geq 100,000 \mathrm{cells} / \mathrm{mL}$ ) and microbiological growth $(\geq 10 \mathrm{cfu} / \mathrm{mL}) . \mathrm{N}=$ number of quarters used in the analysis; AUC = area under the receiver operating characteristic curve; $\mathrm{Se}=$ sensitivity; $\mathrm{Sp}=$ specificity; $+\mathrm{LR}=$ positive likelihood ratio; $\kappa=$ kappa coefficient, which is a measure of agreement between the prediction of subclinical mastitis or IMI based on milk pH higher than the optimal cutpoint and a diagnosis by the reference method. DeLaval cell counter (DeLaval International AB, Tumba, Sweden); Multistix strips (Bayer HealthCare Inc., Elkhart, IN), pH Hydrion paper (Microessential Laboratory, Brooklyn, NY).

${ }^{2} \mathrm{ND}=$ not determined because AUC was not significantly different from 0.50.

${ }^{3} \mathrm{NE}=$ not estimable. 
by an experimental study conducted 50 yr ago, whereby the $\mathrm{pH}$ of quarter milk samples was positively associated with the California Mastitis Test (CMT) reaction, an indirect measure of SCC (Ashworth et al., 1967). However, our results showed that milk $\mathrm{pH}$ does not provide a clinically useful cow-side screening method for detecting mastitis, primarily because milk $\mathrm{pH}$ has a relatively wide range of values, even in uninfected quarters. Combining milk $\mathrm{pH}$ with other diagnostic tests, such as SCC, may improve the clinical utility of milk $\mathrm{pH}$ in detecting quarters with SCM.

The mean $\mathrm{pH}$ of milk samples from healthy quarters $(\mathrm{SCC}<100,000$ cells $/ \mathrm{mL})$ at $37^{\circ} \mathrm{C}$ was lower at freshening (6.40) than at dry off (6.60) in the study reported here. Several other studies have also reported lower milk $\mathrm{pH}$ values in early lactation (Stableforth, 1930; White and Davies, 1958; Klimes et al., 1986; Tsioulpas et al., 2007a). The physicochemical mechanism for the lower $\mathrm{pH}$ of colostrum or the increase in milk $\mathrm{pH}$ in quarters with clinical mastitis or SCM has not been conclusively determined. Extrapolation of physicochemical models developed for plasma (Constable, 1997) and urine (Constable et al., 2009) to milk suggests that an increase in milk $\mathrm{pH}$ in quarters with SCM is primarily due to an increase in the difference between the concentration of the main strong cation in milk (sodium) and the concentration of the main strong anions in milk (chloride and casein), thereby increasing the strong ion difference. Support for this mechanism is provided by studies documenting the changes in milk constituents over the first few days after calving
(Klimes et al., 1986; Tsioulpas et al., 2007a) and quarters with SCM and clinical mastitis (Wielgosz-Groth and Groth, 2003; Bruckmaier et al., 2004; Ogola et al., 2007; El Badawy et al., 2015). It is important to note that milk $\mathrm{pH}$, unlike blood $\mathrm{pH}$, is not tightly regulated, and consequently a larger variation in the milk $\mathrm{pH}$ of healthy quarters is to be expected.

The difference in performance between the $\mathrm{pH}$ meter and the Multistix strip in predicting quarters with SCM was unexpected. The Multistix strip employs the same $\mathrm{pH}$ indicator (bromothymol blue) as the commercially available Mastrip strip that assigns a yellow color (Multistix strip $\mathrm{pH}=6.5$ ) as normal, a light green color (Multistix strip $\mathrm{pH}=7.0$ ) as $\mathrm{SCM}$, a darker green color (Multistix strip $\mathrm{pH}=7.5$ ) as advanced SCM, and a bluish-green color (Multistix strip $\mathrm{pH}=8.0$ ) as clinical mastitis. The colors are the result of bromothymol blue having an acid dissociation constant (pKa) of 7.1; in acidic solutions bromothymol blue is a yellow neutral compound, and upon addition of an alkali bromothymol blue is ionized to a blue form. Hence, when $\mathrm{pH}$ is equivalent to pKa, equal amounts of yellow and blue colors are present, resulting in a green color (Puschett et al., 1991). When using bromothymol blue, the first hints of a light green color become evident when milk $\mathrm{pH} \geq 6.64$ (Baker and Breed, 1920). Recommended $\mathrm{pH}$ cutpoints of $\geq 6.8$ (Prouty, 1934) or $\geq 7.0$ (Udall and Johnson, 1931) at unknown temperature have been suggested to diagnose SCM, similar to the findings in our study. Bromothymol blue has some advantages as a cow-side test to the CMT to diagnose SCM, as bro-
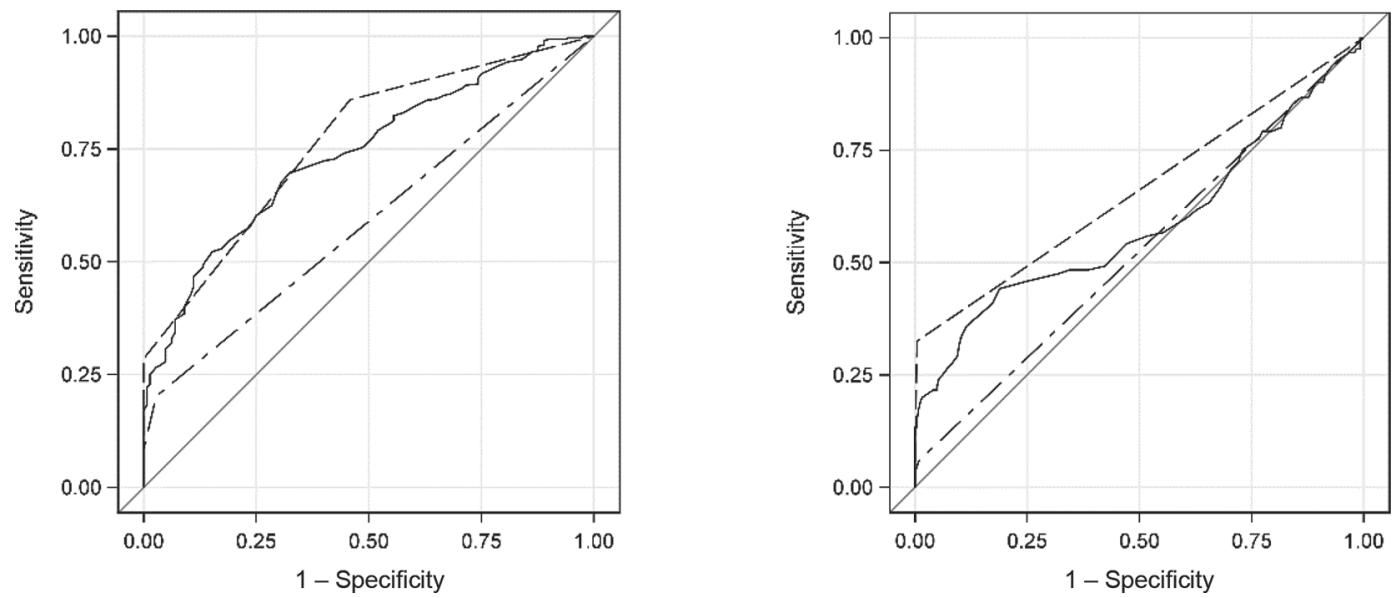

Figure 2. (Left) Receiver operating characteristic (ROC) curves for the ability of milk $\mathrm{pH}$ measured using a pH meter (solid line; Piccolo plus pH meter, Hanna Instruments, Woonsocket, RI), Multistix test strips (dashed line; Bayer HealthCare Inc., Elkhart, IN), and Hydrion pH paper (dash-dot line; Microessential Laboratory, Brooklyn, NY) to detect subclinical mastitis (SCM, defined as SCC >200,000 cells/mL) at dry off. Data were obtained from 456 quarters from 115 cows. The optimal cutpoints for detecting SCM were $\geq 6.67, \geq 7.0$, and $\geq 6.2$ for the pH meter, Multistix test strips, and Hydrion pH paper, respectively. The diagonal line represents the ROC curve for a test of no predictive ability. (Right) ROC curves for the ability of milk $\mathrm{pH}$ measured using a $\mathrm{pH}$ meter (solid line), Multistix test strips (dashed line), and Hydrion $\mathrm{pH}$ paper (dash-dot line) to detect SCM at freshening. Data were obtained from 364 quarters from 92 cows. The optimal cutpoints for detecting SCM were $\geq 6.52, \geq 7.0$, and $\geq 6.2$ for the $\mathrm{pH}$ meter, Multistix test strips, and Hydrion $\mathrm{pH}$ paper, respectively. 
mothymol blue is more objective because color changes are more easily identified than viscosity changes; thus, there is no need to mix equal volumes of reagents and a record of the test result is available for recording at a later time (Marschke and Kitchen, 1985; Tawfik et al., 2014).

The Hydrion $\mathrm{pH}$ paper performed poorly in diagnosing SCM in our study. The unanticipated poor performance of the Hydrion $\mathrm{pH}$ paper may have been due to interference by milk color and viscosity on the reaction with chemicals in the paper, thereby influencing the developed color.

We defined IMI as the presence of SCC $>100,000$ cells $/ \mathrm{mL}$ and isolation of at least $10 \mathrm{cfu} / \mathrm{mL}$ to include infected cows with low pathogen shedding or mild inflammatory response, such as Corynebacterium spp. (Dohoo et al., 2011). We based our diagnosis on a single milk sample from each gland. The $\kappa$ coefficient indicated poor to moderate agreement between the $\mathrm{pH}$ measured by the different investigated methods and IMI at both dry off and freshening. Our failure to isolate microorganisms from quarter milk samples with elevated SCC may be due to bacteria not being the cause of udder inflammation of these glands (unspecific mastitis), low concentration of pathogenic microorganisms in milk, intermittent shedding of pathogens into the glandular secretion, intracellular location of pathogens, the presence of some inhibitors in milk, or the spontaneous elimination of infection from the udder (Constable et al., 2016).

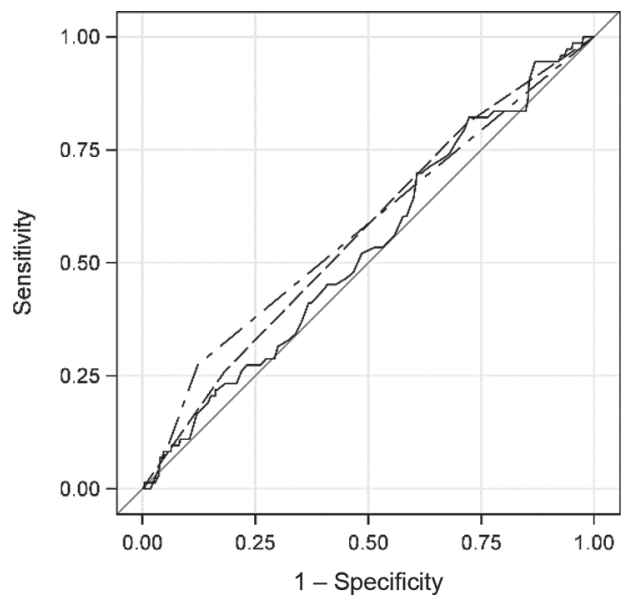

It is important to note that the CMT performed much better as a clinical test to diagnose SCM in our study population than the $\mathrm{pH}$ meter or Multistix strip; a CMT score of trace or higher at dry off had an AUC $=0.88, \kappa=0.77$, Se $=0.95, \mathrm{Sp}=0.81$, and $+\mathrm{LR}=5.0$. Moreover, a CMT score of trace or higher at freshening had an $\mathrm{AUC}=0.87, \kappa=0.76, \mathrm{Se}=0.79, \mathrm{Sp}=0.95$, and $+\mathrm{LR}=39.5$ (Kandeel et al., 2018b). Measurement of milk $\mathrm{pH}$ fell into disfavor as a cow-side test to diagnose SCM following the introduction of the CMT in 1957 (Marschke and Kitchen, 1985), largely because of the lower sensitivity of milk $\mathrm{pH}$ in diagnosing SCM, as demonstrated in our study. The lower test sensitivity for milk $\mathrm{pH}$ is due to the large individual variability in milk $\mathrm{pH}$ in uninfected quarters relative to the small increase in $\mathrm{pH}$ in infected quarters (Cherrington et al., 1933; Figure 1). Application of strong ion difference theory to milk indicates that individual variability in milk $\mathrm{pH}$ in uninfected quarters is primarily the result of individual variability in milk lactose and protein concentrations. This is because milk sodium concentration is inversely related to the milk lactose concentration and, as previously discussed, milk $\mathrm{pH}$ is primarily influenced by the difference between milk sodium concentration and the sum of chloride and casein concentrations. Another potential reason for the large individual variability in milk $\mathrm{pH}$ is that milk $\mathrm{pH}$ changes with the first streams of milk drawn (McDowall, 1941), most likely due to changes in milk lactose, sodium, chloride, and casein concentrations between different milk fractions. A less

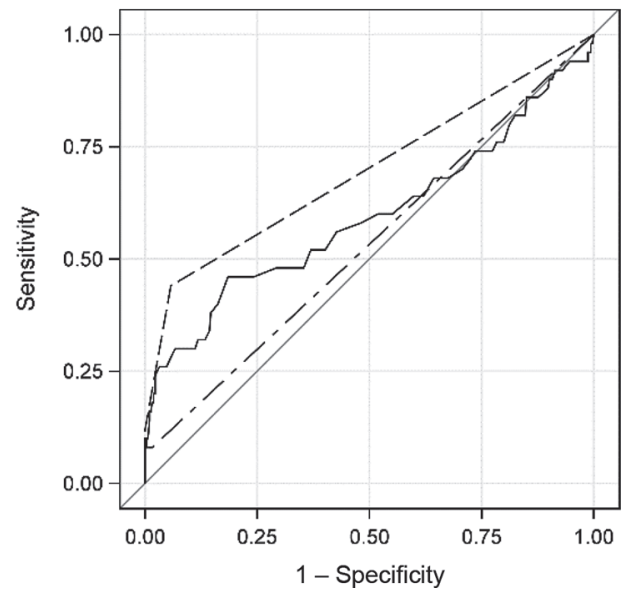

Figure 3. (Left) Receiver operating characteristic (ROC) curves for the ability of milk $\mathrm{pH}$ measured using a pH meter (solid line; Piccolo plus pH meter, Hanna Instruments, Woonsocket, RI), Multistix test strips (dashed line; Bayer HealthCare Inc., Elkhart, IN), and Hydrion pH paper (dash-dot line; Microessential Laboratory, Brooklyn, NY) to detect microbiological growth (MG; defined as $>100 \mathrm{cfu} / \mathrm{mL}$ of milk) at dry off. Data were obtained from 456 quarters from 115 cows. The optimal cutpoints for detecting MG could not be determined for the pH meter and Multistix test strips because the tests were not predictive (95\% CI for area under the curve included 0.50$)$. The optimal cutpoint was $\geq 6.2$ for the Hydrion $\mathrm{pH}$ paper. (Right) ROC curves for the ability of milk $\mathrm{pH}$ measured using a $\mathrm{pH}$ meter (solid line), Multistix test strips (dashed line), and Hydrion pH paper (dash-dot line) to detect MG at freshening. Data were obtained from 364 quarters from 92 cows. The optimal cutpoints for detecting MG could not be determined for the $\mathrm{pH}$ meter and Hydrion $\mathrm{pH}$ paper because the tests were not predictive (95\% CI for area under the curve included 0.50). The optimal cutpoint for detecting MG was $\geq 7.0$ for the Multistix test strips. The diagonal line represents the ROC curve for a test of no predictive ability. 
likely reason for the large individual variability in milk $\mathrm{pH}$ is potential variability in the method for collecting and storing milk samples. Milk partial pressure of $\mathrm{CO}_{2}$ $\left(\mathbf{p C O}_{2}\right)$ is approximately 50 to $55 \mathrm{mmHg}$ in lactating dairy cattle (Van Slyke and Baker., 1919; Linzell and Peaker, 1975), and the loss of $\mathrm{CO}_{2}$ from milk during hand stripping for sample collection and storage in an open container results in an increase in milk $\mathrm{pH}$ (Van Slyke and Baker, 1919; McDowall, 1941; Hotchkiss et al., 2006). However, the maximal increase in milk pH due to the loss of all milk $\mathrm{pCO}_{2}$ is $<0.14 \mathrm{pH}$ units, and in uninfected quarters the maximal increase in milk $\mathrm{pH}$ due to the loss of all milk $\mathrm{pCO}_{2}$ is $0.06 \mathrm{pH}$ units (Van Slyke and Baker, 1919). The calculated variability in milk $\mathrm{pH}$ due to the potential variability in the loss of carbon dioxide during sample collection and storage is therefore much lower than the observed variability. Moreover, we standardized the method of sample collection and storage before $\mathrm{pH}$ measurement in the study reported here.

\section{CONCLUSIONS}

We concluded that milk $\mathrm{pH}$ does not provide a clinically useful cow-side screening method for predicting SCM or IMI at dry off and freshening in lactating dairy cattle.

\section{ACKNOWLEDGMENTS}

This work was supported, in part, by the Cultural and Educational Bureau, Embassy of the Arab Republic of Egypt. This report represents a portion of the thesis submitted by the first author to the graduate school of Benha University as partial fulfillment of the requirement for the PhD. Some of the results were presented as an abstract at the 27th ACVIM Forum, Maryland, June 8-9, 2017.

\section{REFERENCES}

Ashworth, U. S., T. L. Forster, and L. O. Luedecke. 1967. Relationship between California mastitis test reaction and composition of milk from opposite quarters. J. Dairy Sci. 50:1078-1082.

Baker, J. C., and R. S. Breed. 1920. Reaction of milk in relation to the presence of blood cells and of specific bacterial infections of the udder. J. Biol. Chem. 43:221-235.

Batavani, R. A., S. Asri, and H. Naebzadeh. 2007. The effect of subclinical mastitis on milk composition in dairy cows. Ir. J. Vet. Res. 8:205-211

Bruckmaier, M., E. Ontsouka, and W. Blum. 2004. Fractionized milk composition in dairy cows with subclinical mastitis. Vet. Med. Czech. 49:283-290.

Chaplin, L. C., and R. L. J. Lyster. 1988. Effect of temperature on $\mathrm{pH}$ of skim milk. J. Dairy Res. 55:277-280.

Cherrington, V. A., H. C. Hansen, and W. V. Halversen. 1933. The leucocyte content of milk as correlated with bacterial count and hydrogen ion concentration for the detection of mastitis. J. Dairy Sci. 16:59-67.

Constable, P. D. 1997. A simplified strong ion model for acid-base equilibria: Application to horse plasma. J. Appl. Physiol. 83:297311.

Constable, P. D., C. C. Gelfert, M. Fürll, R. Staufenbiel, and H. R. Stämpfli. 2009. Application of strong ion difference theory to urine and the relationship between urine $\mathrm{pH}$ and net acid excretion in cattle. Am. J. Vet. Res. 70:915-925.

Constable, P. D., K. W. Hinchcliff, S. H. Done, and W. Gruenberg 2016. Mastitis. Chapter 20, Pages 2113-2208 in Veterinary Medicine: A Textbook of the Diseases of Cattle, Horses, Sheep, Pigs and Goats. Elsevier Health Sciences, Amsterdam, the Netherlands.

DeLong, E. R., D. M. DeLong, and D. L. Clarke-Pearson. 1988. Comparing the areas under two or more correlated receiver operating characteristic curves: a nonparametric approach. Biometrics 44:837-845.

Dixon, B. 1963. The effect of temperature on the $\mathrm{pH}$ of dairy products Aust. J. Dairy Technol. 18:141-144.

Djabri, B., N. Bareille, F. Beaudeau, and H. Seegers. 2002. Quarter milk somatic cell count in infected dairy cows: a meta-analysis. Vet. Res. 33:335-357.

Dohoo, I. R., and K. E. Leslie. 1991. Evaluation of changes in somatic cell counts as indicators of new intramammary infections. Prev. Vet. Med. 10:225-237.

Dohoo, I. R., J. Smith, S. Andersen, D. F. Kelton, and S. Godden. 2011. Diagnosing intramammary infections: Evaluation of definitions based on a single milk sample. J. Dairy Sci. 94:250-261.

El Badawy, S. A., A. M. Amer, G. M. Kamel, K. M. Eldeib, and P. D. Constable. 2015. Comparative pharmacokinetics using a microbiological assay and high performance liquid chromatography following intravenous administration of cefquinome in lactating goats with and without experimentally induced Staphylococcus aureus mastitis. Small Rumin. Res. 133:67-76.

Grimes, D. A., and K. F. Schulz. 2005. Refining clinical diagnosis with likelihood ratios. Lancet 365:1500-1505.

Hamann, J. 2003. Definition of the physiological cell count threshold based on changes in milk composition. Mastitis Newsletter No. 25, International Dairy Federation, Brussels, Belgium.

Hanuš, O., K. Sojková, K. Hanušová, E. Samková, M. Hronek, R. Hyšpler, J. Kopecký, and R. Jedelská. 2014. An experimental comparison of methods for somatic cell count determination in milk of various species of mammals. Acta Univ. Agric. Silvic. Mendel. Brun. 59:67-82

Hotchkiss, J. H., B. G. Werner, and E. Y. Lee. 2006. Addition of carbon dioxide to dairy products to improve quality: A comprehensive review. Compr. Rev. Food Sci. Food Saf. 5:158-168.

Kandeel, S. A., M. E. Ebied, F. K. Arnaout, E. M. Galila, A. A Megahed, and P. D. Constable. 2017. Clinical utility of two leukocyte esterase reagent strips for the cow-side diagnosis of subclinical mastitis in lactating dairy cattle. Assiut Vet. Med. J. 63:1-10.

Kandeel, S. A., A. A. Megahed, F. K. Arnaout, and P. D. Constable. 2018b. Evaluation and comparison of two on-farm tests for estimating somatic cell count in quarter milk samples from lactating dairy cattle. J. Vet. Intern. Med. 32:506-515.

Kandeel, S. A., A. A. Megahed, M. E. Ebied, and P. D. Constable. 2019. Evaluation of 3 esterase tests for the diagnosis of subclinical mastitis at dry-off and freshening in dairy cattle. J. Dairy Sci. 102:1402-1416. https://doi.org/10.3168/jds.2017-14345.

Kandeel, S. A., D. E. Morin, C. D. Calloway, and P. D. Constable. 2018a. Association of California Mastitis Test Scores with intramammary infection status in lactating dairy cows admitted to a veterinary teaching hospital. J. Vet. Intern. Med. 32:497-505.

Kawai, K., T. Hayashi, Y. Kiku, T. Chiba, H. Nagahata, H. Higuchi, T. Obayashi, S. Itoh, K. Onda, S. Arai, R. Sato, and T. Oshida. 2013. Reliability in somatic cell count measurement of clinical mastitis milk using DeLaval cell counter. Anim. Sci. J. 84:805-807.

Klimes, J., P. Jagos, J. Bouda, and S. Gajdusek. 1986. Basic qualitative parameters of cow colostrum and their dependence on season and post-partum time. Acta Vet. Brno 55:23-39. 
Landis, J. R., and G. G. Koch. 1977. The measurement of observer agreement for categorical data. Biometrics 33:159-174.

Langer, A., S. Sharma, N. K. Sharma, and D. S. Nauriyal. 2014. Comparative efficacy of different mastitis markers for diagnosis of subclinical mastitis in cows. Int. J. Appl. Sci. Biotechnol. 2:121-125.

Linzell, J. L., and M. Peaker. 1975. The distribution and movements of carbon dioxide, carbonic acid and bicarbonate between blood and milk in the goat. J. Physiol. 244:771-782.

Ma, Y., and D. M. Barbano. 2003. Milk pH as a function of $\mathrm{CO}_{2}$ concentration, temperature, and pressure in a heat exchanger. J. Dairy Sci. 86:3822-3830.

Malinowski, E., S. Smulski, M. Gehrke, A. Kłossowska, A. Arczyńska, and M. Kaczmarowski. 2008. Effect of storage conditions and preservation with Bronopol on somatic cell count with the DeLaval cell counter in cow milk. Med. Weter. 64:1299-1303.

Marschke, R. J., and B. J. Kitchen. 1985. Detection of bovine mastitis by bromothymol blue pH indicator test. J. Dairy Sci. 68:12631269.

Maunsell, F. P., D. E. Morin, P. D. Constable, W. L. Hurley, G. C. McCoy, I. Kakoma, and R. E. Isaacson. 1998. Effects of mastitis on the volume and composition of colostrum produced by Holstein cows. J. Dairy Sci. 81:1291-1299.

McDowall, F. H. 1941. Studies on the detection of mastitis in New Zealand dairy herds. II. Factors influencing the bromthymol blue test for mastitis. N. Z. J. Sci. Technol. 27:258.

National Mastitis Council (NMC). 1999. Microbiological Procedures for the Diagnosis of Bovine Udder Infection. National Mastitis Council. 3rd ed. NMC, Arlington, VA.

National Research Council (NRC). 2001. Nutrient Requirements of Dairy Cattle, 7th rev. ed. Natl. Acad. Sci., Washington, DC.

Nguyen, D. A. D., and M. C. Neville. 1998. Tight junction regulation in the mammary gland. J. Mammary Gland Biol. Neoplasia $3: 233-246$.

Ogola, H., A. Shitandi, and J. Nanua. 2007. Effect of mastitis on raw milk compositional quality. J. Vet. Sci. 8:237-242.

On-Nom, N., A. S. Grandison, and M. J. Lewis. 2010. Measurement of ionic calcium, $\mathrm{pH}$ and soluble divalent cations in milk at high temperature. J. Dairy Sci. 93:515-523.

Prouty, C. C. 1934. A comparison of the leucocyte count, the brom thymol blue reaction and the catalase content of freshly drawn milk. J. Dairy Sci. 17:75-81.

Puschett, J. B., B. S. Rao, B. M. Karandikar, and K. Matyjaszewski. 1991. Indicator characteristics of bromothymol blue derivatives. Talanta 38:335-338.

Pyörälä, S. 2003. Indicators of inflammation in the diagnosis of mastitis. Vet. Res. 34:565-578.

Qayyum, A., J. A. Khan, R. Hussain, M. Avais, N. Ahmad, and M. S. Khan. 2016. Investigation of milk and blood serum biochemical profile as an indicator of sub-clinical mastitis in Cholistani cattle. Pak. Vet. J. 36:275-279.

Sarikaya, H., and R. M. Bruckmaier. 2006. Importance of the sampled milk fraction for the prediction of total quarter somatic cell count. J. Dairy Sci. 89:4246-4250.

Schalm, O. W., and D. O. Noorlander. 1957. Experiments and observations leading to development of the California mastitis test. J. Am. Vet. Med. Assoc. 130:199-204.

Schukken, Y. H., D. J. Wilson, F. Welcome, L. Garrison-Tikofsky, and R. N. Gonzalez. 2003. Monitoring udder health and milking quality using somatic cell counts. Vet. Res. 34:579-596.

Stableforth, A. W. 1930. Studies on bovine mastitis: II. Diagnosis by means of the reaction of the milk to brom-cresol-purple. J. Comp. Pathol. Ther. 43:22-39.

Sundareshan, S., S. Isloor, Y. H. Babu, B. Awati, R. Hegde, R. Sunagar, C. B. Waryah, J. Gogoi-Tiwari, T. K. Mukkur, and N. R. Hegde. 2014. A comparative evaluation of four detection tests and the isolation of coagulase-negative staphylococci from subclinical mastitis cases in south Indian cattle. Indian J. Comp. Microbiol. Immunol. Infect. Dis. 35:73-78.

Swets, J. A. 1988. Measuring the accuracy of diagnostic systems. Science 240:1285-1293.

Tawfik, N. F., B. A. Effat, K. E. Shafei, R. E. Dairouty, and O. M. Sharaf. 2014. Mastitis and antibiotic residues in Egyptian raw milk with lactic acid bacteria population in dairy products retailed in Cairo and Giza area. Glob. Vet. 13:696-703.

Tsioulpas, A., A. S. Grandison, and M. J. Lewis. 2007a. Changes in physical properties of bovine milk from the colostrum period to early lactation. J. Dairy Sci. 90:5012-5017.

Tsioulpas, A., M. J. Lewis, and A. S. Grandison. 2007b. A study of the $\mathrm{pH}$ of individual milk samples. Int. J. Dairy Technol. 60:69-97.

Udall, D. H., and S. D. Johnson. 1931. The diagnosis and control of mastitis. Cornell Vet. 21:190-206.

Van Slyke, L. L., and J. C. Baker. 1919. Carbonic acid and carbonates in cow's milk. J. Biol. Chem. 40:335-344.

White, J. C. D., and D. T. Davies. 1958. The relation between the chemical composition of milk and the stability of the caseinate complex. I. General introduction, description of samples, methods and chemical composition of samples. II. Coagulation by ethanol. III. Coagulation by rennet. J. Dairy Res. 25:236-280.

Wielgosz-Groth, Z., and I. Groth. 2003. Effect of the udder health on the composition and quality of quarter milk from black-and white cows. Electron. J. Pol. Agric. Univ. 6:2-5.

Zhao, X., and P. Lacasse. 2008. Mammary tissue damage during bovine mastitis: Causes and control. J. Anim. Sci. 86(Suppl.):57-65. 